\title{
Retracted: Web Application To Monitor Logistics Distribution of Disaster Relief Using the CodeIgniter Framework
}

\author{
Mohamad Jamil ${ }^{\mathrm{a}, 1^{*}}$, Mohamad Ridwan Lessy ${ }^{\mathrm{b}, 2}$ \\ a) Departement Informatics Engineering, Faculty of Engineering, Khairun University, Jl. Pertamina Kampus II Unkhair \\ Gambesi Kota Ternate, Maluku Utara, Indonesia 97719 \\ b) Departement Marine Science Study Program, Faculty of Fisheries, Khairun University, Jl. Pertamina Kampus II \\ Unkhair Gambesi Kota Ternate, Maluku Utara, Indonesia 97719 \\ ${ }^{I}$ Email: jamil@unkhair.ac.id; mrlessy@yahoo.com ${ }^{2}$
}

\section{RETRACTED}

Article history:

Received

Revised

Accepted

Keywords:

Application

Disaster

Monitoring

Web

Framewok
Following a rigorous, carefully concerns and considered review of the article published in International Journal of Artificial Intelligence Research to article entitled "Web Application To Monitor Logistics Distribution of Disaster Relief Using the CodeIgniter Framework" Vol 1, No 2, pp. 47-53, December 2017, DOI: 10.29099/ijair.v1i2.23

This paper has been found to be in violation of the International Journal of Artificial Intelligence Research Publication principles and has been retracted.

The article contained redundant material, the editor investigated and found that the paper published in IOP Conference Series: Materials Science and Engineering Volume 325 on International Conference on Information Technology and Digital Applications (ICITDA 2017), https://iopscience.iop.org/article/10.1088/1757899X/325/1/012015/meta

The document and its content have been removed from International Journal of Artificial Intelligence Research, and reasonable effort should be made to remove all references to this article.

Copyright $\odot 2017$ International Journal of Artificial Intelegence Research. All rights reserved. 